\title{
An Analysis of Socialist Modernist Heritage in Roma- nia and the Republic of Moldova through Case Studies: Utilitarian Buildings and Industrial Facilities
} Dumitru RUSU

\begin{abstract}
The "Socialist Modernism" Project is part of an initiative by B.A.C.U. Association focused on protecting built heritage in the former socialist bloc. In that respect, we have launched a campaign for the preservation of buildings that are specific to the socialist modernist period (1955-1991). The architecture of the socialist period, more precisely the modernist tendencies in 1955-1991, is a specific trend in the evolution of architecture in the former socialist bloc. There is increasing international awareness for this trend, as indicated by the creation of scientific communities (the SocHeritage Platform, part of the ICOMOS International Scientific Committee for the $20^{\text {th }}$ century). The chosen period in our study was set by historic events that led to this new architectural tendency. At the time, the approach was inspired by modernist architecture, which came to the capitalist states in Western Europe with a set of principles. In socialist countries, modernist trends first influenced the professional sphere, and through that influence, they were able to penetrate borders and the limits imposed by ideology. The current orientations regarding built heritage in Romania and the Republic of Moldova are the preservation of local cultural identity and the coherent management of the existing built patrimony. The listed heritage of Romania and the Republic of Moldova includes a variety of objectives, from prehistoric settlements to 20th-century buildings, but those from the socialist period are systematically ignored. One of the actions initiated as part of our program was to launch procedures in order for buildings from representative industrial ensembles in Romania and the Republic of Moldova to be classified as Historical Monuments. They are the ones presented in these case studies, among others: Buzau - the Sugar Factory (1965); Bucharest - the Worsted Mill (1965); and Chișinău - the Fashion House (the '70s). Although the age of the buildings is an important criterion in establishing historic value today, the architectural features of these buildings, their planimetric and structural coherence are enough to qualify them as highly valuable. Also, they point out the socialist constructive doctrine, being representative for the way that the light and the heavy industry buildings of the time were built and standardized.
\end{abstract}

Keywords: Socialist Architecture, Urban Heritage, Architectural Heritage, Utilitarian Buildings, Industrial Buildings. 


\section{Context}

Socialist architecture (1933-1991) and the trends of those decades of socialist realism and modernism are becoming more and more popular in specialists' circles. One of the reasons may be that, until recently, they have been insufficiently explored in the broader context of global architecture, and therefore are considered a mere curiosity by many experts.

The two trends (socialist realist and socialist modernist architecture) were ignored both locally and globally, and not just by experts, but also by the public authorities. We refer to authorities in the former Eastern bloc (Romania, the Republic of Moldova, Poland, Hungary, Ukraine, etc.).

Socialist Modernism is a specific approach to architecture in former socialist countries, between 1955 and 1991, insufficiently covered by architecture history treaties. The Modernist trend was officially adopted after a historical event: in 1955, a decision of the Central Committee of the USSR Communist Party announced that "useless stylistical elements" in architecture will be abandoned. The decision followed Nikita Khrushchev's appeal, made one year before at the Union Conference of Builders, Architects and Workers in Construction Materials Industry, Construction Machines Industry, Planning and Research". From there on, Stalinist (or realist-socialist) architecture was replaced throughout the socialist bloc. In socialist countries, modernist trends first influenced the professional sphere, and through that influence, they were able to penetrate borders and the limits imposed by ideology.

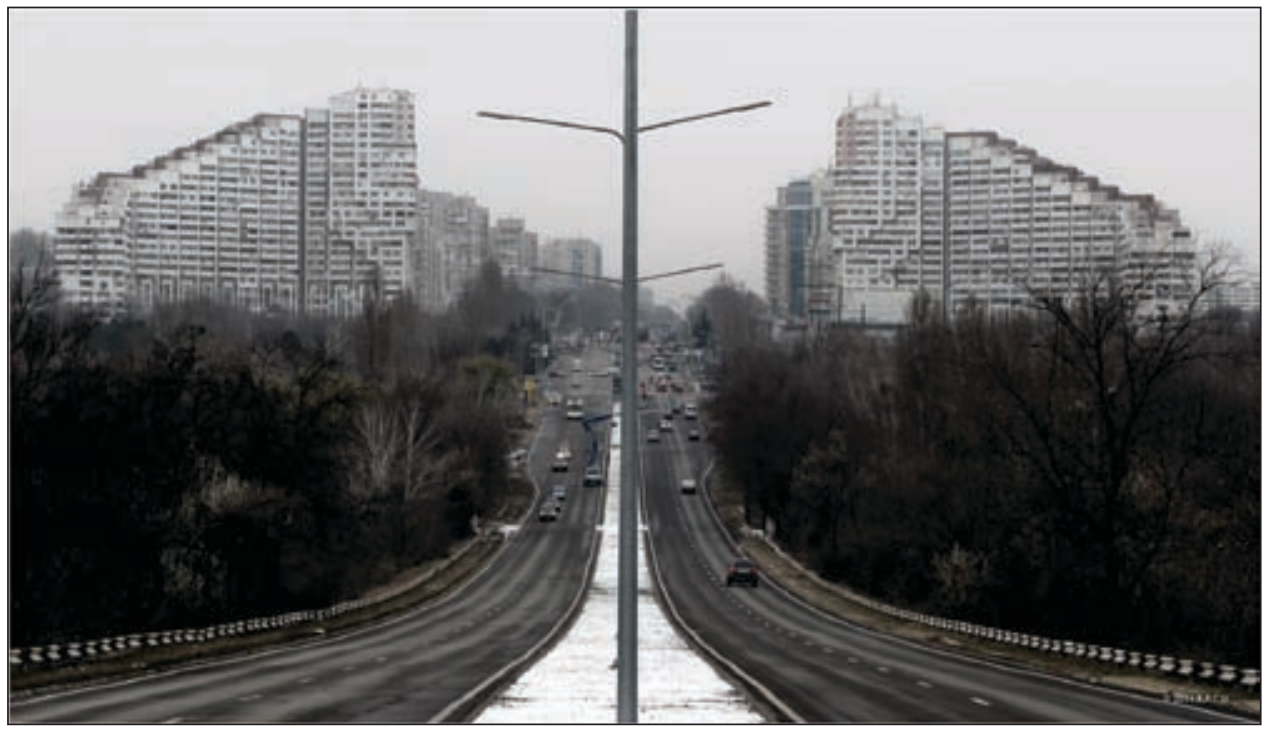

Figure 1. An illustrative image for the situation of the built environment in Chișinău, the Republic of Moldova (BACU Association Photo department, ca. 2014) 
The "Socialist Modernism" Project is part of an initiative by B.A.C.U. Association (Birou pentru Artă și Cercetare Urbană). Our approach is focused on protecting built heritage in the former socialist bloc. In that respect, we have launched a campaign for the preservation of buildings that are specific to the socialist modernist period (1955-1991), by protecting, monitoring, researching and preserving the most valuable architecture of the time, including monuments, buildings, parks, squares, whole neighbourhoods, laid-out green areas, etc.

Our purpose is to rehabilitate this heritage, not only for symbolic reasons but because we have faith in these elements, which were able to overcome ideological pressure and managed to give urban space a certain, very specific savour in socialist cities. Unfortunately, this type of architecture is associated with totalitarianism. This is exactly what we are trying to clarify: we want to prove that the architecture of that time is valuable, and we can do that by analysing the significance of the socialist period in a wider historical context, without partisanship for the political system.

Between 1955 and 1970, the Republic of Moldova and Romania experienced a strong urban development, as a result of industrialization, visible in all cities and districts. In large and medium cities (Chișinău, Bucharest, Bacău, Pitești, and others), collective living neighbourhoods (micro districts) built during that period covered large areas and included all complementary functions (health, education, culture, shopping, sports, utilitarian buildings, industrial ensembles, etc.).

\section{The current state of socialist modernist heritage}

Unfortunately, today in towns and cities of Moldova and Romania, many socialist modernist objects (culture houses, shops, medical facilities, buildings transport, stadiums, utilitarian buildings, factories, etc.) are abandoned or are in an advanced state of decay, some of them even close to ruin.

The current orientations regarding built heritage in Romania and the Republic of Moldova are the preservation of local cultural identity and the coherent management of the existing built patrimony. The listed heritage of Romania and the Republic of Moldova includes a variety of objectives, from prehistoric settlements to 20th-century buildings, but those from the socialist period are systematically ignored. One of the actions initiated as part of our program was to launch procedures to let the buildings from representative industrial ensembles in Romania and the Republic of Moldova be classified as Historical Monuments. They are the ones presented in the following case studies: Buzau - the Sugar Factory (1965); Bucharest - the Worsted Mill (1965-2020); Cluj-Napoca - the Telephone Palace (1969-75); and Chișinău - the Fashion House (the '70s). 


\section{Sugar Factory, 7 Industriei Boulevard, Buzau, Romania}

The factory was designed to produce sugar from sugar beetroot and raw sugar from sugar cane. Today, the production unit in Buzau, where the sugar cane is processed, has a capacity of 1,000 tons per day. The administrative building is shaped like a perfect cube, reminding of a sugar crystal. The constructive structure is entirely precast, made of thick slab floors, from pre-slabs with an additional thin pour of concrete over the top. In 1998, the Buzau sugar factory was taken over by a foreign company and technologically modified to process only raw sugar. The building is in an acceptable state of conservation; only the façades of the administrative building require urgent cleaning.

\section{"Alexandru Sahia" Woolen Mill, \\ 59 Vergului Road, Bucharest, Romania}

The former woollen mill in Bucharest, (today, Filan S.A.) was initially a small factory. It was modernized by reorganizing the spaces of the mill and connecting them to those of the new factory (the fibre blending and fibre dyeing section, with a capacity to dye about 10 tons of fibres per day), on a total surface of about 14,000 sq.m. Unifying the constructive system had the benefit of bringing all the specific functions of each workshop into a single volume building (that lines our different streets). The use of simple architecture, outlining the constructive elements and technological functions, is noticeable. The current owners rent out the spaces of the complex, now in a serious state of degradation, to various businesses: two laundries, a restaurant and two preschools. Recently the complex was demolished to make room to a new development.

\section{Danubiana Industrial Complex, 181 Oltenitei Road, Popesti-Leordeni, Romania}

Danubiana Tyre Plant in Popești-Leordeni was notable for its simple, typically socialist modernist architecture. The travertine-plated façade of the production halls displayed a monumental composition with an ideological theme signed by painters Gheorghe Labin, Horea Maxy and Stefan Szanyi. Today, only the administrative building and a few other spaces, now for rent, have survived. The Danubiana complex, producing tyres and other rubber materials, was built in the '60s. In 1995 it was privatized alongside 100 hectares of land. The new owners promised to make substantial investments but failed to do so and the company was reorganized in 2006 - a good way to sell away the land. The complex was dismantled and the production units demolished. 


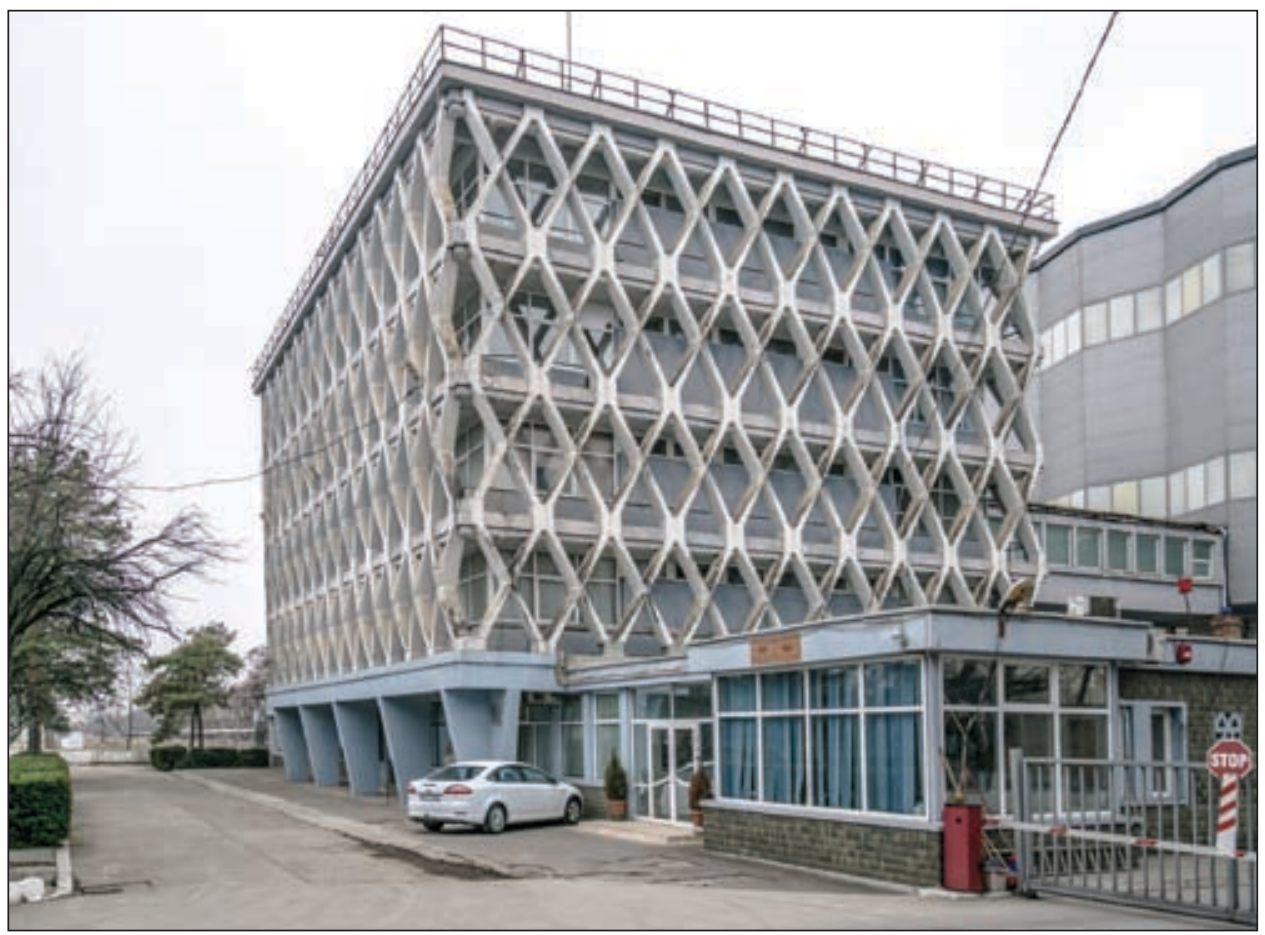

Figure 2. Sugar Factory in Buzau, Romania (BACU Association Photo department, ca. 2015)

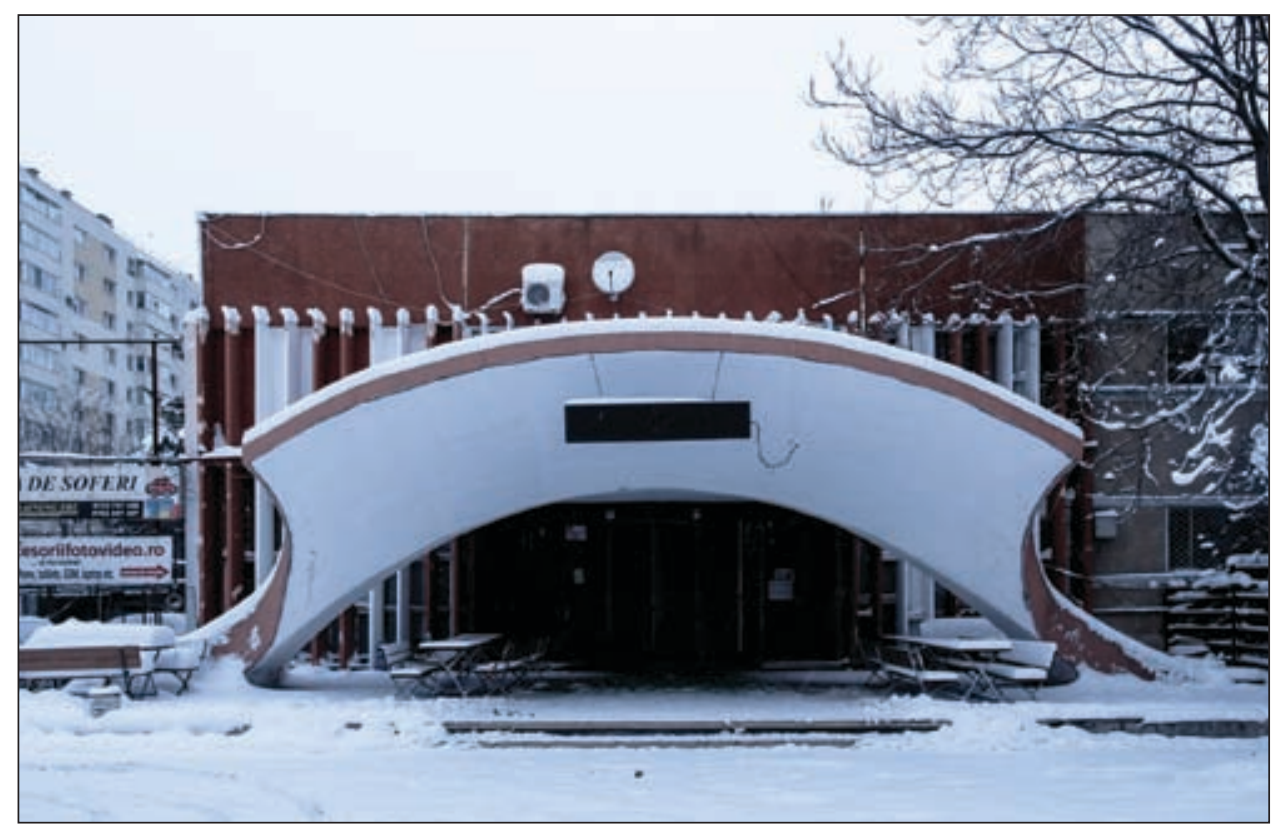

Figure 3. "Alexandru Sahia" Woollen Mill in Bucharest, Romania (BACU Association Photo department. circa 2017) 


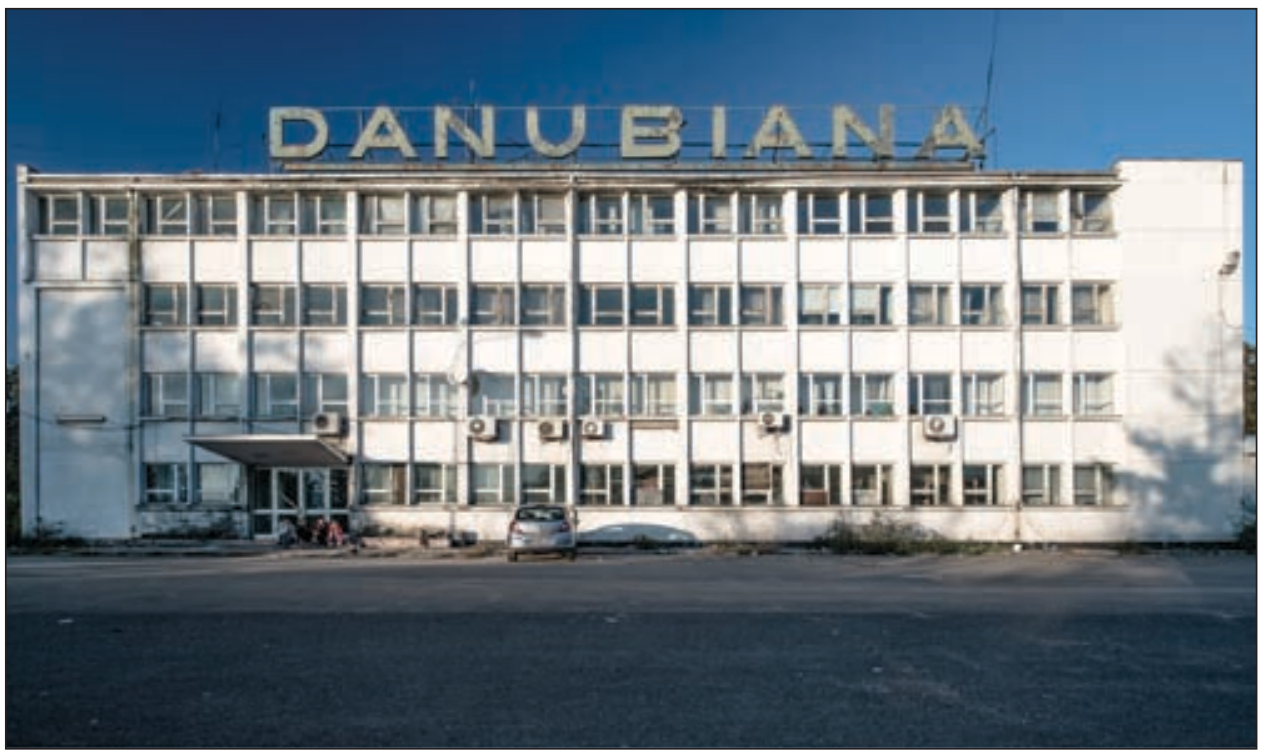

Figure 4. Danubiana Industrial Complex in Popești-Leordeni, Romania (BACU Association Photo department. circa 2015)

\section{The Postal Palace, 2 Octavian Petrovici Street, Cluj-Napoca, Romania}

In 1969, after a technological study by the Telecommunications Design Institute, a plan was drafted for a $\mathrm{G}+5$, building, and a $\mathrm{G}+3$ was constructed in the first stage. Public and administrative spaces were grouped on the ground floor, while the upper floors hosted the telecommunication equipment. Today, the building is covered in graffiti and visibly decayed. The first register of the façade is strewn with air-conditioning units and unsightly cables that seriously alter its aspect. A stylized map of Cluj-Napoca, created after drawings by the architect and installed on the façade, near the main entrance, was removed in 2010 and probably sold as scrap iron, despite its value, with no reaction from the authorities. In 2018, BACU proposed the building, now owned by Telekom, for listing by the Romanian Ministry of Culture.

\section{Fashion House, 182 Stefan cel Mare și Sfânt Boulevard,}

Chișinău, Republic of Moldova

The Chișinău Fashion House, located downtown, a symbol of Moldovan fashion design in the '70s, was planned as a tall rectangular volume pierced by a cube elevated on reinforced concrete columns. The ground floor and first floor hosted the presentation store, while the other levels were reserved for produc- 


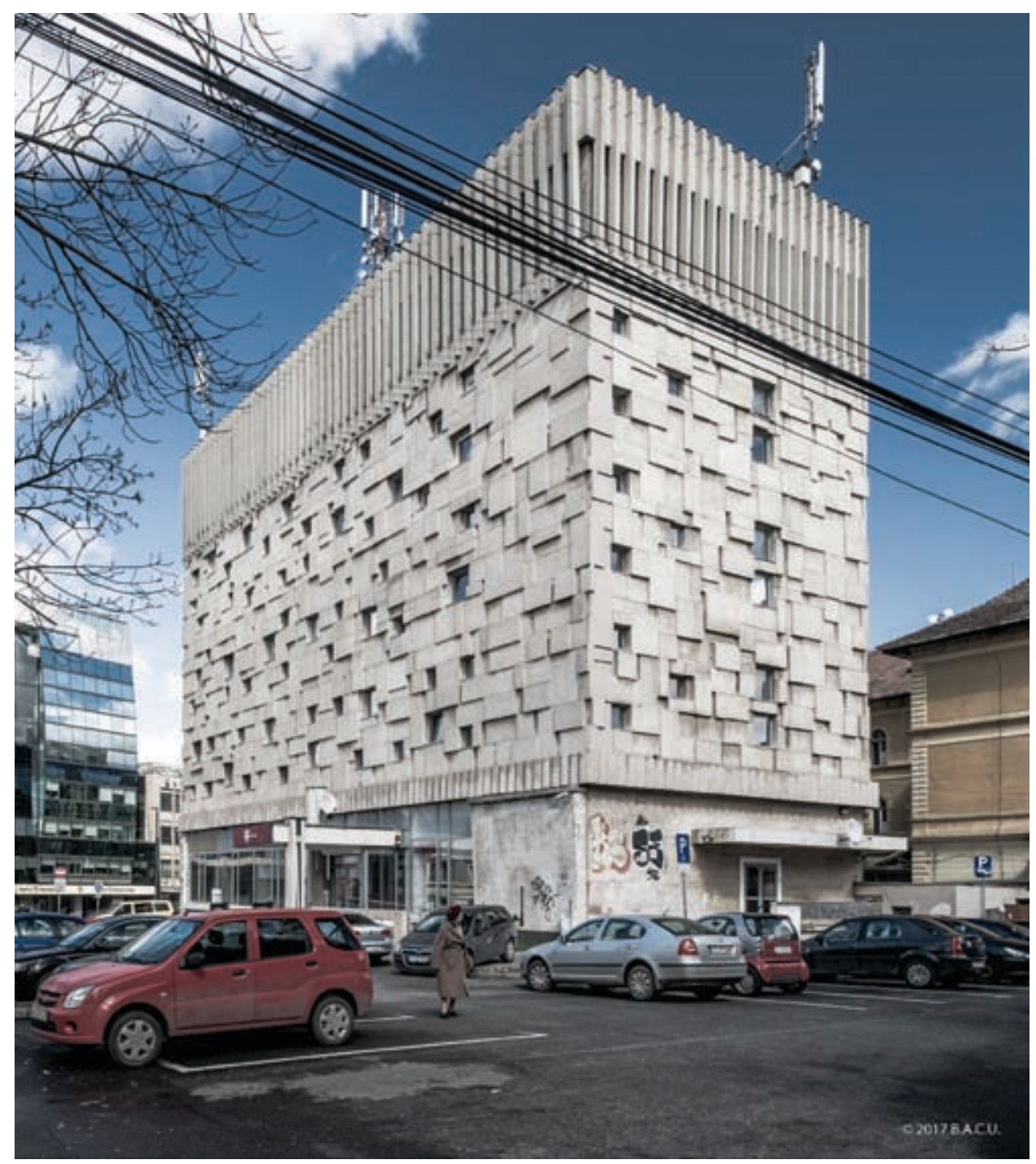

Figure 5. The Postal Palace in Cluj-Napoca, Romania (BACU Association Photo department. circa 2017)

tion workshops. Currently, the building is in an advanced state of degradation, although the structure is still in good shape. The exterior finishings show mechanical wear, with several places where the plaster is completely or partially peeled off. The parasite buildings that surround the Fashion House, such as Felicia Pharmacy or La Plăcinte Restaurant, alter its original architectural aspect.

And the list is very long with many other modernist examples in similar situations in both countries. 


\section{Proposed solutions}

It was a time when the built environment knew a sharp increase, explaining why these buildings form the large majority in many socialist cities. If these urban areas are not protected as a whole, the general image of the city will suffer.

Hence the idea to advocate for their protection, restoration, and rehabilitation. We want to preserve the historical value of socialist modernist buildings while improving the overall urban aspect. Looking at the current economic and political situation, we may foresee a dark future for socialist buildings, many of them in the process of demolition or inadequate repairs. Many are surrounded by parasitic structures or rehabilitated with low-quality materials, threatening not just the safety of the future tenant, but also the image of the city.

At the same time, society holds resentments against this type of architecture, because of the policies enforced by socialist authorities. Often, this heritage is not seen for what it is, a complex of architecture objects or urban ensembles, but as a result of bad policies.

I will briefly introduce two initiatives that follow a series of actions to preserve the heritage of the socialist period.

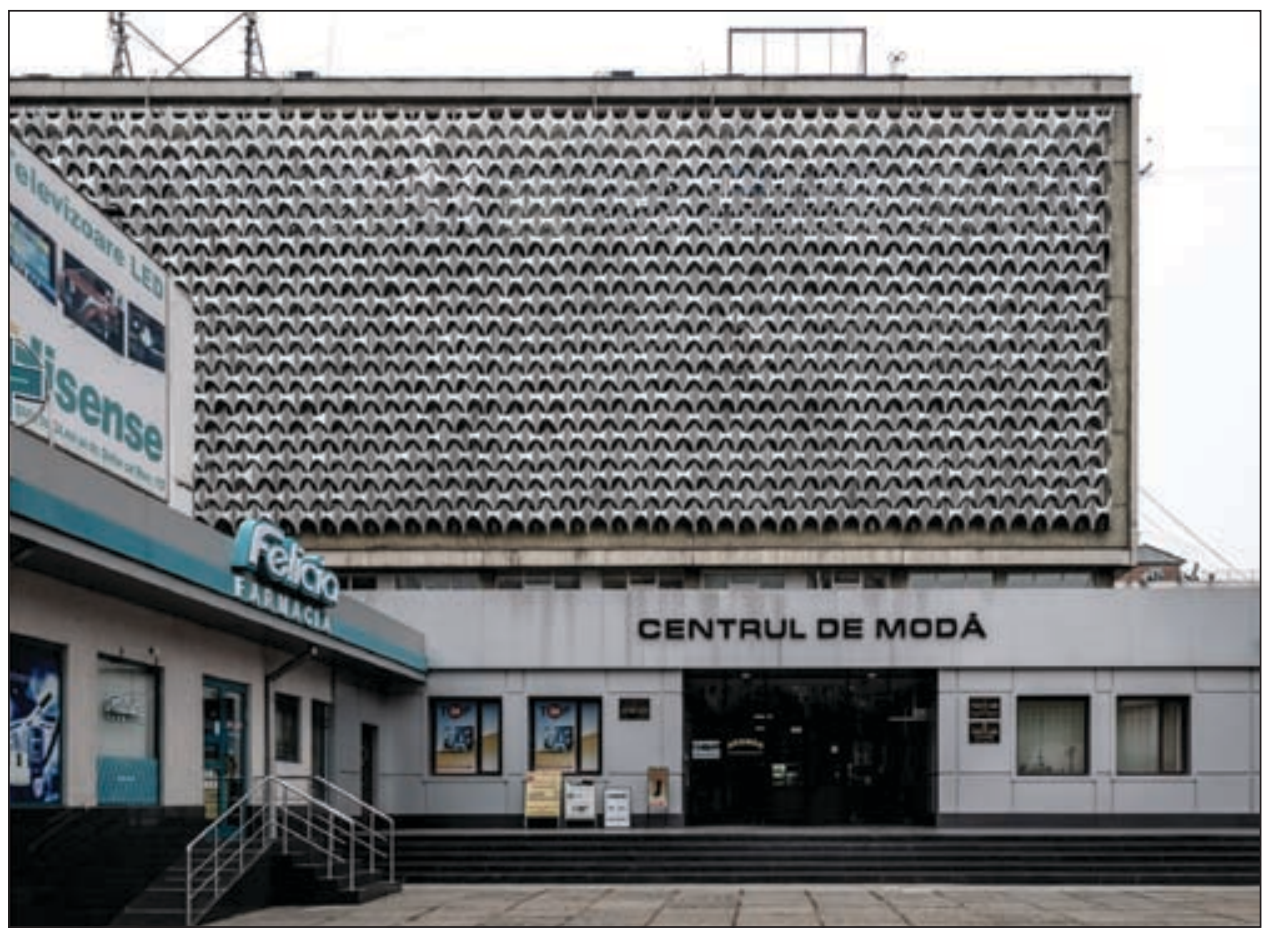

Figure 6. The Fashion House in Chișinău, Moldova (BACU Association Photo department. circa 2017) 
SocHeritage platform is a BACU Association project supported by ICOMOS ISC20C. It advocates for socialist architecture and artworks to be recognized and protected as cultural landmarks and historic monuments. We focus on buildings in the former socialist bloc, built between 1933-1991 in Central and Eastern Europe (CEE), as well as in Central Asia and other regions. The platform intends to collect and provide information on location and site, the current condition of conservation, the authors and the planning and building history of socialist legacy.

An important part in safeguarding socialist heritage is played by the "Socialist Modernism” initiative. Its actions are directed at rehabilitating and conservation of buildings in Central and Eastern Europe. The project is taking into account the uncertain legal situation of most of these modernist buildings/ complexes, but even though it hinders our efforts, this challenge does not discourage us because most of these objectives are alarming.

Our initiatives seek stylistic discipline and the involvement of both local authorities and the civil society in this process, to raise awareness to the architectural value of the buildings, urban planning and the social and cultural urban tissue still existing. We are currently working on revitalization proposals for several socialist modernist objectives built in cities/municipalities of Romania and the Republic of Moldova. The proposals suggest the demolition of parasitic structures; prohibiting the closing of balconies and any type of DIY abusive rehabilitation; removing excessive advertising from the facades and, finally, making these neighbourhoods, buildings, leisure facilities, parks etc. part of the historical heritage.

\section{Conclusions}

The Bureau for Urban Art and Research (B.A.C.U.) is an organization focused on urban and cultural conservation and rehabilitation activities. Its main directions are to protect, preserve and rehabilitate built heritage and art from the socialist period, as well as to monitor how architectural heritage in Central and Eastern Europe is maintained, protected and preserved. Apart from preserving the historical value of the buildings, the Association is also interested in improving the overall urban landscape. B.A.C.U. is also striving to make it possible for certain architectural ensembles, buildings and other valuable objects to be classified as heritage and legally protected, both locally and internationally. In 2016, the Association initiated the classification process for four socialist modernist buildings in Chișinău, the Republic of Moldova. On August 8,2019, the State Circus in Chisinau became a protected monument after a decision of the National Historical Monument Committee of the Moldovan Ministry of Culture. 


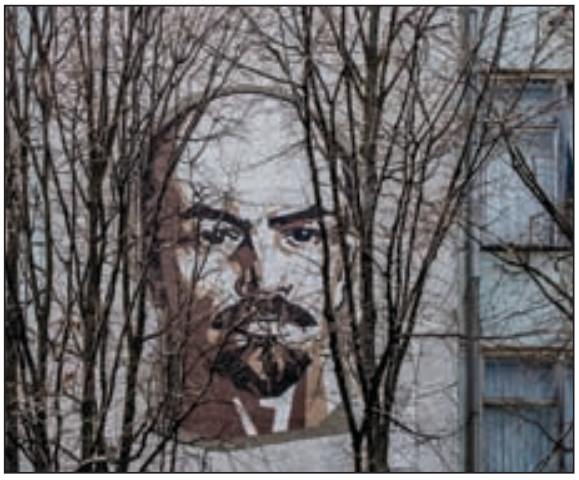

Figure 6. The former factory "L. I. Lenin", the 1960s. Bălți, Moldova (BACU Association Photo department. circa 2017)
Under such circumstances, the legislation on socialist heritage protection needs to be reviewed, because, at least in Romania and the Republic of Moldova, it is not serving its purpose. We are interested in preparing a draft bill that would help preserve these architectural objects and the specific atmosphere it created. The bill will have the object of preserving built architectural heritage, setting directions for its revitalization and supporting projects for the classification and conservation of buildings in a bad state of decay.

Although the age of the buildings is an important criterion in establishing their historic value today, the architectural features of these buildings, their planimetric and structural coherence are enough to qualify them as highly valuable. Also, they point out the socialist constructive doctrine, being representative for the way that the light and the heavy industry buildings of the time were built and standardized.

Another argument for listing these buildings as historic monuments is the observation that liberal policies promoted by both countries over the last decades have badly neglected the socialist architectural and urban heritage of the cities. A whole series of very valuable buildings are not on the Historic Monuments Register/List and are in a menacing state of decay. In such a context, listing socialist modernist buildings and starting restoration programs for them (first of all for those most decayed, which need urgent protection) must be the next step in saving the built heritage of Romania and the Republic of Moldova.

\section{Bibliography}

Asociaţia BACU (2017). Modernismul Socialist in România si Republica Moldova. Bucharest: Editura BACU.

Asociaţia BACU (2018). Ghid - Arhitectura Modernist socialistă - România si Republica Moldova. Bucharest: Editura BACU.

Ioan, A. (2009). Modern Architecture and the Totalitarian Project - a Romanian case study. Bucharest: Romanian Cultural Institute Publishing House.

Kolotovkin, A.V., S.M. Shoikhet, I.S. Eltmann (1987). Architektura Sovetskoj Moldavii = Architecture of the Soviet Moldavia, 319 s.: zahlr. Abb. Moskva: Strojizdat.

Muth, S., F. Wolf (2009). The linguistic landscapes of Chișinău: Forms and functions of urban public verbal signs in a post - Soviet setting. Lancaster University Postgraduate Conference. 
Panaitescu, A. (2012). From Scanteii House to People's House. Four decades of architecture in Bucharest 1945-1989. Bucharest: Simeria Publishing.

Ritter, K., E. Shapiro-Obermair, D. Steiner, A. Wachter (2012). Soviet Modernism 1955-1991. Wien: Ed. Park Books.

\section{O analiză a patrimoniului socialist modernist din România și Republica Moldova prin studii de caz: clădiri utilitare și facilități industriale}

\section{Rezumat}

Proiectul „Modernismul socialist” face parte dintr-o inițiativă a B.A.C.U., asociație axată pe protejarea patrimoniului construit în fostul bloc socialist. În acest sens, am lansat o campanie pentru conservarea clădirilor specifice perioadei socialiste moderniste (1955-1991). Arhitectura perioadei socialiste, mai precis elementele moderniste din 1955-1991, reprezintă o tendinţă specifică în evoluția arhitecturii din fostele state socialiste. Există o conştientizare internațională crescândă pentru această tendință, după cum se indică prin crearea comunităților științifice (Platforma SocHeritage, parte a Comitetului științific internațional ICOMOS pentru secolul al XX-lea). Perioada de timp vizată în studiul nostru, a doua jumătare a sec. XX, a fost stabilită de evenimente istorice care au condus la această nouă tendinţă arhitecturală. La acea vreme, abordarea era inspirată de arhitectura modernistă, care a ajuns în statele capitaliste din Europa de Vest cu un set de principii. În țările socialiste, tendințele moderniste au influențat mai întâi sfera profesională și prin această influență au reușit să pătrundă granițele și limitele impuse de ideologie, condiționând decizii politice importante. Patrimoniul listat al României și Republicii Moldova include o varietate de obiective, de la așezările preistorice până la clădirile din secolul XX, dar cele din perioada socialistă sunt ignorate sistematic. Acţiunile inițiate ca parte a programului nostru au fost lansarea procedurilor pentru ca clădirile din ansamblurile industriale reprezentative din România și Republica Moldova să fie clasificate ca Monumente Istorice. Obiectivele abordate în studiului nostru sunt: Buzău - Fabrica de zahăr (1965); București - Filatura și finisajul de lână „Alexandru Sahia” (1965-2020) și Chişinău - Casa de modă (anii '70), a căror valoare este determinată de criteriul vechimii, dar mai ales de cel al coerenței şi specificităţii planimetrice şi structurale. Un alt argument pentru enumerarea acestor clădiri ca monumente istorice este observația că politicile liberale promovate de ambele țări în ultimele decenii au neglijat grav patrimoniul arhitectural și urbanist socialist al orașelor. O serie întreagă de clădiri foarte valoroase nu se regăsesc pe Registrul/Lista monumentelor istorice și se află într-o stare amenințătoare de degradare.

Cuvinte cheie: arhitectură socialistă, patrimoniu urban, patrimoniu arhitectural, clădiri utilitare, clădiri industriale.

Dumitru Rusu, Bureau for Art and Urban Research (BACU), Bucharest, email: office@bacu.ro 